\title{
Some Issues about the Decisions of the Courts for Divorce in Albania
}

\section{Denada Shpuza}

\author{
Lawyer at Regional Education Department of Shkodra, Albania \\ PhD Candidate on Private Law at European University of Tirana, Albania \\ Email: shpuzadenada@hotmail.com
}

\author{
Doi:10.5901/mjss.2015.v6n5p76
}

\begin{abstract}
Over these last 25 years, Albania has gone through social, political and economic changes. All these changes affect the society at large but also, more speciffically the life of the family. These changes exposed the necessity for a new which will the regulate the family relations in the in the context of a the new changes that were accompanying the society. Despite the past 12 years since its entry into force, it has not suffered any changes. In the recent years we have observed a growing number of divorces in the Albanian society. This has come also as a consequence of various factors of which to be mentioned are: the difficult economic conditions; immigration; the emancipation and developments that our society has undergone and specifically the Albanian woman who is no longer accepting to live in a systematic violence of psychological, physical and economic nature; the empowerment of women in our society, etc. The marriage is resolved when the decision rendered by a competent court has become final. The dissolution of marriage does not end the life of a family. The decision of marriage dissolution and its execution is faced in more than a few cases with some conflict situations that live more discretion to the courts, which in many cases affect the child's interest but also the family relations in general. These problemtics will be treated further in this paper.
\end{abstract}

Keywords: Dissolution of marriage, the higher interest of the child, family life, court decision

\section{Introduction}

In order for a marriage to be resolved, firstly it must have started in the form required by law. The marriage is resolved by final decision rendered by a competent court. The court's decision to dissolve the marriage is variable in relation with the exercise of parental responsibility and the food payment amount. (FC 2003 article 159) The decision for marriage dissolution and the evaluation of the ex-spouses' obligations in many cases puts the court in dilemmas which not always find the answer in the Family Code. The execution of the Court's decisions is also a part of it, and sometimes it can prove very difficult, or even impossible. This difficulty lies not only in the failure to execute the decision of one party but also by the unwillingness of one of the parties to execute it, thus becoming an obstacle to the other party. The Court's decision for marriage dissolution in cases when the spouses have a child, charges both parties with rights and obligations, being thus equally binding on both parties. On the other hand, it is worth mentioning that non-fulfillment of the obligations by one party should not lead to the failure of the obligation fullfillement by the other party.

\subsection{What the spouses require in the petition for divorce?}

As above quoted, in order for a marriage to be resolved, firstly it must have started in the form required by law, if not so will be the case of a null or null and void marriage. A marriage can be resolved when the court decision has become final. This decision is binding on the parties.

The dissolution of marriage may be made by agreement between the spouses or by a court claim made to a competent judge. According to the dissolution of marriage by agreement between the parties, the Family Code has dedicated only a few articles leaving room for interpretation by the Court, but what is worth noting is the fact that the parties decide by agreement about their rights and obligations, an agreement which, if not impinge the fundamental rights and freedoms of any of the spouses but mainly the interest of the children, is aprooved by the Court giving to this aprooval the power of a judicial decision since it becomes part of the court's decision.

In this case the question arises: Can this decision, which contains the drafted agreement approved by both spouses, be changed on demand after its aproval?

During the draft agreement the parties may agree about the child custody and the monthly payment amount, but this agreement is bond by the conditions at the time of the agreement drafting. When these conditions change, the 
change of the court decision may also be required. The court's decision in this case has legitimated the demands expressed in the agreement between the spouses at the time of the agreement.

Besides the divorce by agreement, marriage solution can be done also through a claim, where one party appeal to the court with a lawsuit claim, where besides the request for marriage dissolution the demand for other requirements can be raisen, such as:

$>$ The change or otherwise of the wife's surname.

$>$ The responsibility for the child's upbringing and education.

$>$ Setting of the maintenance payment for the child and the other spouse as a compensation.

$>$ Scheduling the days for the meetings of the not-custodian parent with the child/children, holidays, summer holidays, etc.

$>$ The right of the spouse who will care for raising and the education of the children, to use the apartment of the other spouse, until the children become adults.

These are the spouses' demands in terms of rights and obligations they have in relation to each other and to their children, but not including obligations arising from the division of marital property, because regardless the economic character of food pensions and the right to use the apartment, these rights are not to be counted in the mutual property division but only as obligations they have as a result of this new situation created in their relationship after the divorce.

\subsection{Does the marriage dissolution end the family life?}

Dissolution of marriage with a final decision rendered by a competent court ends the marriage but not the family life, even less does it so for the obligations the parents have towards their children as the exercise of parental responsibility. (FC 2003, article 154)

Despite the end of the marriage, it does not end the obligations of spouses to contribute in the growth and education of their children. Despite the claim may be submitted by one spouse, it does not deny to the other spouse the right to claim his/her own pretences about the childrens' custody primarily as the right to set up a counterclaim, alleging for the right of custody to one or several children. Thus, in the court situations may occur where a decision is to be made on some requests of the parties that do not comply with the law. (Civil Procedure Code article 29)

The law does not expressly regulate the situation where the childrens' custody is required by both parents; the amount of food annuity that parents have to pay for children; the days where the child/children will meet the parent to whoom is not assigned his/her custody, etc., but the court gives a final settlement after evaluating the factual circumstances, the economic conditions provided by each parent to the child, the child's age, the attitude of the parents towards their children and foremost deciding in every case on the best interests of the children (Fc 2003, article 2)

Giving a fair decision is the duty of the court, but it is not enough. A court decision which is not executed is equivalent with a not taken at all decision, or it results in violation of the rights and fundamental freedoms of the individual. The purpose for obtaining a judicial decision is to give a solution to a conflict between the parties. If the final decision is not applied we can say that the conflict is not resolved.

In this regard, the court should be very careful in making a decision that is possible to execute.

\section{Method}

\subsection{Mixed methods of research}

The author decided to use mixed research methods because of the advantage of mixed methods. It is argued that mixed research methods have several advantages. Mixed methods provide guidance for others in connection eith what researchers are intended to do or have done (Creswell 2003). The Family Code adopted in 2003 has followed no changes despite the constant changes experienced by the society and the increasing number of divorces.

\section{Materials}

Quantitative data of court decisions statistics Provided by the Albanian Ministry of Justice.Qualitative researching on decisions about divorce made by Court Districts, Appeal Courts, High Court of Albania and the Eurpoean Court of Human Rights. We will use some of their findings to elaborate our results. 


\section{Results}

The purpose of this paper is to assess the problemtics the courts encounter during the divorce decisions, the execution of these decisions and the identification of the cases where the interest of children or spouses are affected by the courts' decisions due to the discretion given by law to the judges in such decisions. Given that the Family Code came into force 12 years ago and during these 12 years an increased number of divorces is observed, we consider it necessary to make some amendments to the FC.

\section{Findings}

\subsection{What are the problematics encountered in the judicial practice regarding the divorce decisions of the courts?}

District Courts and various Appeal Courts in some cases have decided that the child's custody should be exercised by both parents, scheduling accordingly the days of the week for each parent. The Court's argument for that decision is the child's/childrens' necessity to maintain continuous contact with both parents, while in fact, such a decision creates instability not only to both ex-spouses who are headed to the Court in order to end the marital relationship, but it creates an instability also to the child/children, especially when they are of school age, by moving from one parent to the other. During their reasoning for the decisions taken in these cases, the Courts try to argument that the decision is protecting the best interest of the child, who must have constant connections with both parents, deciding that the parental responsibility shall be exercised three and a half days by one parent and three and a half days by the other parent.

Such a court decision creates problems not only for the children and the parents but also for other civil bodies for which the implementation of it is mandatory, such as the Civil Status Office. The Civil Judicial Panel of the High Court shares this same view about the abovementioned issue also well argued in its decision (High Court Decision No. 270, dated 24.05.2012) On the other hand, the CSO is unable to execute the court's decision because the same decision does not speciffy the certificate of whose parent will be used for the registration of the child/children. Under these conditions the court should be very cautious in its decision, always protecting the best interest of the child as this is the main task of the court. Also, it is worth mentioning that it is the duty of the court to make the decisions clear, understandable, and wellargued.

Another problem that emmerges in these decisions is when the child's custody is requested by both parents. As we quoted above the law does not expressly adjust to whom the children are assigned when both parents want their custody, leaving this to the discretion of the court, which as noted above several times, should give priority the protection of the Child's best interests. In some cases the protection of the child's interest have been suspicious when the court, for the sake of protecting the interests of the children have decided to sepparate them assigning their custody to different parents. It is true that each child can have a greater affective connection with one parent than the other, but it is equally true that children growing up together in the same environment can face more easily with the dissolution of the marriage of their parents. The parents' separation is a consequence of the divorce but it should not be accompanied also by the separation of their children by protecting the sole interests of one or the other parent. With such decisions the courts actually decide the separation of the children, who at best will meet once a week with each other over the weekend. I belive that the courts should give more attention to the issues of divorce when the couple has more than one child and both parents have requested their custody.

Another issue encountered in the case of divorce and in those cases similar to the above-mentioned cases, is the right of the child for a food support payment or alimentary pension. In cases when the court decides the separation of children to different parents, the court does not impose the obligation of either ot the parents to pay the food pension, albeit that its goal is to provide a better living for the child.

In our opinion the court have not analysed the circumstances righteously. Both parents have the responsibility for the raising of their children and for their education but one parent may be in more favorable economic conditions than the other. The economic conditions should not be the criterion by which the court is guided in making the decision for the the child's custody.

In these cases, we think that the court should impose an obligation for the spouse with better economic conditions to pay the food pension in favor of the child who is left to be raised and educated by the parent who does not have good economic conditions. The purporse of the alimentary pension aims that the parent gives his contribution to the child's upbringing and education regardless of whom the custody have been asigned to. Such decision will help in eradicating the economic disproportions of childrens' raising.

Another problem is encountered in many cases when the court gives more priority to the economic situation and 
living conditions of the spouses, as the main criterion for deciding on child's custody. As we quoted above, in the case of economic change, this criterion should not be primary for the Court but it should give importance to the care that parents show for the growth and education of the child, and even force the other parent to take all the necessary measures for the child to grow in better conditions than those the other parent guarantees if it is the parent that with commitment, work, and patience, manages to provide a psychosocial stability in the growth and education of the child/children, regardless the economic situation.

According to the right recognized by the Family Code for the use of the apartment by the non-owner spouse and his/her obligation to pay a rental fee to the owner spouse we are of the opinion that this Article is a bit discriminatory to bashkëshortin. This discrimination lies in the fact that this criterion will directly affect the economy not only of the nonowner spouse but that of his/her family as well, because that economy include also the living conditions of the child/children entrusted to him/her. The spouse who have this right to use the ex-spouses' apartment, is the spouse to whom the kids are assigned for growth and education. This obligation, I believe that unfairly burden the spose who provides for the children growing and education. Referring to this legal provision, in many cases the judges make decisions to impose an obligation to the owner spouse to pay the alimentary pension for the child in the same amount of the rental fee the other spouse whose the child's custody is assigned to, is obliged to pay to the owner spouse. Such a decision means, the obligation of one party versus the other party's obligation, regardless of the fact that the first obligation relates to the improvement of child's life and must pass directly to his/her better growth, while the second obligation favors the economic position of the other parent who has no other obligations in the growth and education of the child.

As this right is only recognized to the spouse whom the childrens' growth and education are assigned to until a certain age, we think that at this point the Family Code should be amended with the aim to help in this way the spouse who does not own a house to live in with the ex-couples' children. Setting of the lease means less income to be used for the child's upbringing and education, income that will go to the owner parent. We think that the very purpose of the legislator in setting such a provision was to assist the spouse who has nowhere to live, but to whom is assigned the custody of the child since he/she is the parent who provides a greater psycho-social stability for the child's growth and education. The right to use this house aims to help in rising the child and just relates it to the child since this right is recognised to the non-owner spouse only when he/she is assigned with the responsibility of childrens' growth and education until they reach 18 , or 25 if still in school.

The setting of parental responsibility and the manner it is exercised by the ex-spouse parents, is a duty for the court as much as it is an obligation for the parties to execute its decision. In many cases the execution of this decision becomes impossible, especially for today society's conditions where people are free to move in EU countries, and not only. We above quoted that the court decide on the exercise of parental responsibility by the parents. We also highlighted the fact that in making this decision, the court must protect the best interests of the child as a whole, setting the terms on how can the parental responsibility be exercise, but without violating the rights of the other parent. In this context the question arises:

\subsection{How can the parental responsibility be exercised when one parent is not in Albania, where the parent who have earned the child's custody is located?}

As mentioned before, the exercise of parental responsibility is fair as well as parental detyre. The parental responsibility translates not only into the economic contribution of the parent to the child but also into providing advice, opinions, suggestions, meetings about upbringing and education of the child. If the parent to whom the court didn't assign the raising and education of the child, is forced, for different reasons to leave the common residence of the spouses, which means the city, village, state, etc, this does not mean that he/she loses the right and obligation to exercise the parental responsibility.

It would be better that both spouses agree on the manner of realization of the other parent meetings with the child, the continued communications between the parents by technological means such as phone, skype etc. that in one way or another reduce the distances. On the other hand, the parents can agree for more frequent meetings when the before absent parent comes in Albania, or for the opportunity to meet the parents at the place of his/her residence. As well noted above, it is very important between divorced parents an agreement on co-parenting or exercising of parental responsibility, in order that the court decision is executed as far as possible from both parents without becoming obstacles to the exercise of their rights and obligations if these are in the interest of the child. (ECHR 2000-VIII).

On the other hand the question arises:

Does the divorced parent to whom the raising and education of a child have been assigned, have also the right to 
leave Albania together with the child/children in custody for vacation, medical visit, etc.?

Leaving of this parent will make it impossible the execution of the court's decision regarding the right of the noncustodial parent to meet the child/children, therefore it is mandatory the consent of the non- custodial parent. Not giving this consent would put the other parent in a difficult position if he/she would try to cross the border with the child/children. Moving of the child inside or outside the country should be made by an agreement of both parents drafted before a notary. Suffice mentioning here the case Bajrami against Albania regarding the prevention of the custodial parent in executing the Court decision and specifically the part that has to do with the right of the father to meet with his child.

This case brings to our attention another specificity of the parenthood responsibility: it must be exercised by the parent to whom it is assigned by a court decision and not by other persons or even relatives, because the non-exercise of the parental responsibility by the parent to whom it has been assigned that right and other duties by a court decision, impinges the court's decision thus affecting the best interest of the child that have been taken into account by the court while making this decision, and also puts at risk the parent of losing that right through a claim that can be presented to the court by the interested parties. The bitter fact is that, in many cases, the parents become themselves obstacles for ensuring a better life to their children, even though they themselves did not contribute nor they contribute at all to provide a better life for their child/children, thereby preventing the custodial parent to leave Albania with the child/children toward another place where they can try to provide a better life. The Family Code does not provide any solutions for this situation, leaving an unfavorable situation for the custodial parent who fails to provide even the vital minimum in Albania, while on the other hand the non-custodial parent does not even minimally respond for the upbringing and education of the child, with the excuse that he/she doesn't provide enough income.

\section{The Execution of the Decision in Relation to the Alimentary Pension}

The parent to whom are assigned the upbringing and education of the child, is entitled to ask to the other parent to pay an alimentary pension for for the child. The amount of this pension is determined by the court after itt has assessed the needs of the child but also the income of the custodial parent, and that of the non-custodial parent who must pay the alimentary pension. The making of this decision is a duty of the court, but its execution is the duty of the non-custodial parent and at the same time is a right of the custodial parent to address the competent authorities, namely the executive office to seek its mandatory execution, if it is not voluntarily executed.

The exercise of the parental responsibility is one of the requests submitted by the parties before the court seek for a solution. The parental responsibility in itself includes rights and obligations. The rights and obligations consist not only on the psycho-social contribute but also on the economic one, because a child needs psycho-social support in addition to the economic stability in his/her everyday needs. This contribution is mandatory from the birth moment of child until he/she reaches the age of 25 years if still continues to go to school.

The Family Code does not include this obligation for the time when the mother is pregnant if the child has not yet come into life, and in the meantime the marriage is dissolved, since the child's needs begin at that moment even though he/she has not yet come to life. The Code does not specify if the alimentary pension will continue throughout the life of the child who can be really an adult but on the other hand is a person with disabilities regardless of the pension that the state provides him due to his health condition.

Problems encountered in connection with the execution of this part of the decision are:

$>$ The husband is unemployed, which is also the cause for dissolution of the marriage.

$>$ The husband does not fully declare the income he provides from his work.

$>$ The husband works in in black in a state body.

$>$ The husband is an immigrant, and his income is unknown.

$>$ None of the assets the husband has are registered in his name.

All these reasons make it impossible to execute the court decision. The decision is mandatory not only to the custodial spouse, but also to the other spouse who among other things will respond financially for the child's upbringing and education. The preceding cases show that the decision is unlikely to be executed or at least competent authorities have not made sufficient efforts to execute it. But it is worth mentioning that such a decision includ not just the interests of two adults, the ex-spouses, but also a direct interest of a minor, namely the child to whom will be assigned the alimentary pension.

The Constitutional Court itself, with its Decision No. 24, dt.21.04.2015 has estimated that:

"the execution of the decision constitutes an essential element of the rule of law and the very notion of a fair trial. No state organ can not put into question the fairness of the final judicial decisions, but is obliged to take appropriate 
measures for their implementation. The execution of a final decision of the court is considered the final stage of a judicially awarded right, because only after its implementation the individual can be sure for having fully set in place his awarded right".

All isntitucions should take all the necessary steps for the execution of the obligation either voluntarily or compulsory, in order to have justice and above all to protect the interests of the minor.

\section{Discussions}

\subsection{How should the parental responsibility be exercised?}

Court Decision No .270, dated 24.05.2012 which says that interest in the protection of the best child's interests, "the parental responsibility shall not be exercised jointly by both parents on certain days during the week, because it creates confusion". This decision should be rendered unified and mandatory for all Courts. During the decision for the child's custody, despite the requests of the parents for attaining that custody, the Court should be guided only by the principle of protecting the best interests of the child and such interests can not be protected by a decision which establishes the separation of the children from each other.

To protect the best interests of the child the Courts should not be guided by economic criteria while determining the parental responsibilities, but should compel the parent who have better income to pay in such a way that the child be provided with normal living conditions despite of the fact that he is living with the parent with less income.

In conjunction with Article 153 of the Family Code, which recognizes to the non-owner ex-spouse the right to use the marital home versus a lease that he/she is obliged to pay to the owner ex-spouse. The law relates this right to two moments which are:

1. The non-owner spouse must have attained the custody of the child/children.

2. The lack of another house where he/she can live with the child/children.

The fact that the legislator links this right to the custody of the child, I believe should have been a little more careful and not setting an obligation for the non-owner spouse to pay a rent to the owner spouse for this lease. This rental fee aggravates the position of the custodial spouse who must respond to all the demands of the child/children. The right to use the apartment should be recognized throughout the life of the child if the latter results with disabilities.

According to the right of the custodial spouse to leave Albania, and the obstruction the other spouse could exercise in this case, I believe that at this point the Family Code should be amended with the aim to leave this right to the court, which after assessing the situation and the circumstances must recognize to the custodial parent the right for emigration even without the consent of the non-custodial spouse.

For the setting of the alimentary pension a minimum amount must be fixed by the legislator so that the courts in taking its decision will not make decisions where the it can be below this minimum. This minimum should represent the minimal conditions that can be provided in a month to a child depending on his/her age, to support the child's upbringing and education. This obligation should be recognized from the moment of the child's conception if the couple is separated in the meanwhile and should continue throughout the child's life if the child results a disabled person.

All these issues raise the need for amending the Family Code.

\section{References}

Law no.8417, date 21.10.1998 "Constitution of the Republic of Albania"amanded

Law no.8116, date 29.03.1996 "Civil Procedure's Code of Albanian Republic", amended

Law no.9062, date 08.05.2003 "Family Code" ,amended

Law no.9669, date 21.06.2008 "For measures against violence in family relations" amanded

Law no.10 428, date 02.06.2011, "For private international law "amended

Ksanthipi,B (1984) "The family's right" Mihal Duri pg 289-307

Mandro, A (2009)"The family's right", EMAL pg 296-338

Mandro, A (2014) "Gender discimination in marital and family issue'. School of Magistrate and UNDP pg 101-136

"Manual on the Implementation of the Family Code and the Civil Legislation regarding juvenile issues" School of Magistrates , Save the Children, Centre of Forensic Services and Integrated Practice

Zaçe ,V (1996) "'The relations of marriage under Albanian legislation" pg 124-140 


\section{International Acts}

European Convection of Human Rights International Covenant on Civil and Political Rights Universal Declaration of Human Rights Convention on the rights of the Child

\section{Court Decision}

\section{The European Court of Human Rights}

Bajrami against Albania

Qama against Albania and Italy

\section{Decision of Constuticional Court}

Decision No. 24, dt.21.04.2015

\section{Decision of Tirana's High Court}

Decision No. 270, date 24.05.2012

\section{Webpages}

www.drejtesia.gov.al www.magjistratura.edu.al ceflonline.net/principles http://www.gjykataelarte.gov.al/ 